\title{
Exhumed subglacial landscape in Uruguay: Erosional landforms, depositional environments, and paleo-ice flow in the context of the late Paleozoic Gondwanan glaciation
}

\author{
Mario Luis Assine ${ }^{\mathrm{a}, *}$, Héctor de Santa Ana ${ }^{\mathrm{b}}$, Gerardo Veroslavsky ${ }^{\mathrm{c}}$, Fernando F. Vesely ${ }^{\mathrm{d}}$ \\ a UNESP - Universidade Estadual Paulista, Departamento de Geologia Aplicada, Rio Claro, SP, Brazil \\ b ANCAP - Administración Nacional de Combustibles, Alcohol y Portland Montevideo, Uruguay \\ c UDELAR - Universidad de la República, Facultad de Ciencias, Instituto de Ciencias Geológicas, Montevideo, Uruguay \\ d UFPR - Universidade Federal do Paraná, Departamento de Geologia, Curitiba, PR, Brazil
}

\section{A R T I C L E I N F O}

\section{Article history:}

Received 2 January 2018

Received in revised form 13 March 2018

Accepted 14 March 2018

Available online 17 March 2018

Editor: Dr. J. Knight

\section{Keywords:}

San Gregorio Formation

Chaco-Parana Basin

Late Paleozoic Ice Age

Glacial landforms

Whaleback

Gondwana glaciation

\begin{abstract}
A B S T R A C T
A well-exposed glacial surface sculpted on Precambrian crystalline basement rocks occurs below the glacial succession of the San Gregorio Formation on the eastern border of the Chaco-Parana Basin in Uruguay and was formed in the context of the late Paleozoic Gondwana Ice Age. On the glacial surface are asymmetric parallel streamlined bedrock landforms interpreted as whalebacks. The downglacier (lee-side) faces of the whalebacks have gentle slopes dipping NNW with striated and sometimes polished surfaces on crystalline rocks. These landforms are covered by $10-100$-cm-thick layers of tillites and shear-laminated siltstones, suggesting glacial abrasion produced mainly by subglacial till sliding. The subglacial facies are ice-molded, and exhibit meso-scale glacial lineations such as ridges and grooves up to $30 \mathrm{~m}$ long and $30 \mathrm{~cm}$ deep. The subglacial association is directly overlain by proglacial fine-grained facies (rhythmites) with dropstones indicating a subaqueous depositional environment following ice-margin retreat. The fine-grained facies are erosively cut by a succession of sandstones with wave-generated stratification resting on a basal conglomerate. Intraformational striated surfaces, NNEoriented, were found on four distinct bedding planes within the sandstone package and interpreted as ice keel scour marks produced by floating ice. The San Gregorio deposits are partially confined in a wide and shallow subglacial trough and the stratigraphic succession is interpreted as the record of a glacial advance-retreat cycle comparable to deglacial sequences from other late Paleozoic localities. The paleo-ice flow to the NNW indicated by subglacial lineations is parallel to that verified in the southernmost Paraná Basin located north of the study area, suggesting a paleogeographic scenario in which glaciers advanced northward into a glaciomarine environment. The proposed palaeogeography does not confirm the previous hypothesis of an ice center on the Sul-Riograndense Shield but, instead, it corroborates a south-derived Uruguayan Ice Lobe advancing to the north, probably with provenance far afield in terranes of the present-day southern African.
\end{abstract}

() 2018 Elsevier B.V. All rights reserved.

\section{Introduction}

The palaeogeography and sedimentary archives of the Gondwana basins in the late Paleozoic Ice Age (LPIA) resulted from events of glacial advance and retreat (López-Gamundí and Buatois, 2010) and path polar migration (Caputo and Crowell, 1985; Powell and Li, 1994). Multiple glacial lobes derived either from continental ice sheets or from smaller, topographically controlled ice caps have been interpreted in southeast South America. The reconstruction of these lobes and inferences regarding their paleoflow direction are mainly supported by erosional glacial

\footnotetext{
* Corresponding author.

E-mail addresses: assine@rc.unesp.br (M.L. Assine), hdesantaana@ancap.com.uy (H. de Santa Ana), gerardo@fcien.edu.uy (G. Veroslavsky), vesely@ufpr.br (F.F. Vesely).
}

landforms incised in the preglacial substrate, such as striated pavements, streamlined landforms, and glacial troughs and valleys (e.g., Frakes and Crowell, 1969; Rocha-Campos et al., 1988; Gesicki et al., 2002; Trosdtorf et al., 2005; Rosa et al., 2016; Fallgatter and Paim, 2017).

In the Chaco-Parana Basin (Uruguay), locally named the Norte Basin, glacial striations were used as evidence for a Gondwanan glaciation and to support the hypothesis of continental drifting by Du Toit (1927). The idea of a south-derived "Uruguay ice lobe" in the context of the LPIA was proposed by Frakes and Crowell (1972) while the disputing hypothesis of an ice-spreading center irradiating from the Sul-Riograndense Shields was defended by Santos et al. (1996).

The late Paleozoic San Gregorio Formation is a stratigraphic unit of the Chaco-Parana Basin that encompasses the sedimentary records of the LPIA in Uruguay (Fig. 1). Subglacial facies and erosional landforms are rare in exposures of the San Gregorio Formation, which deposits 

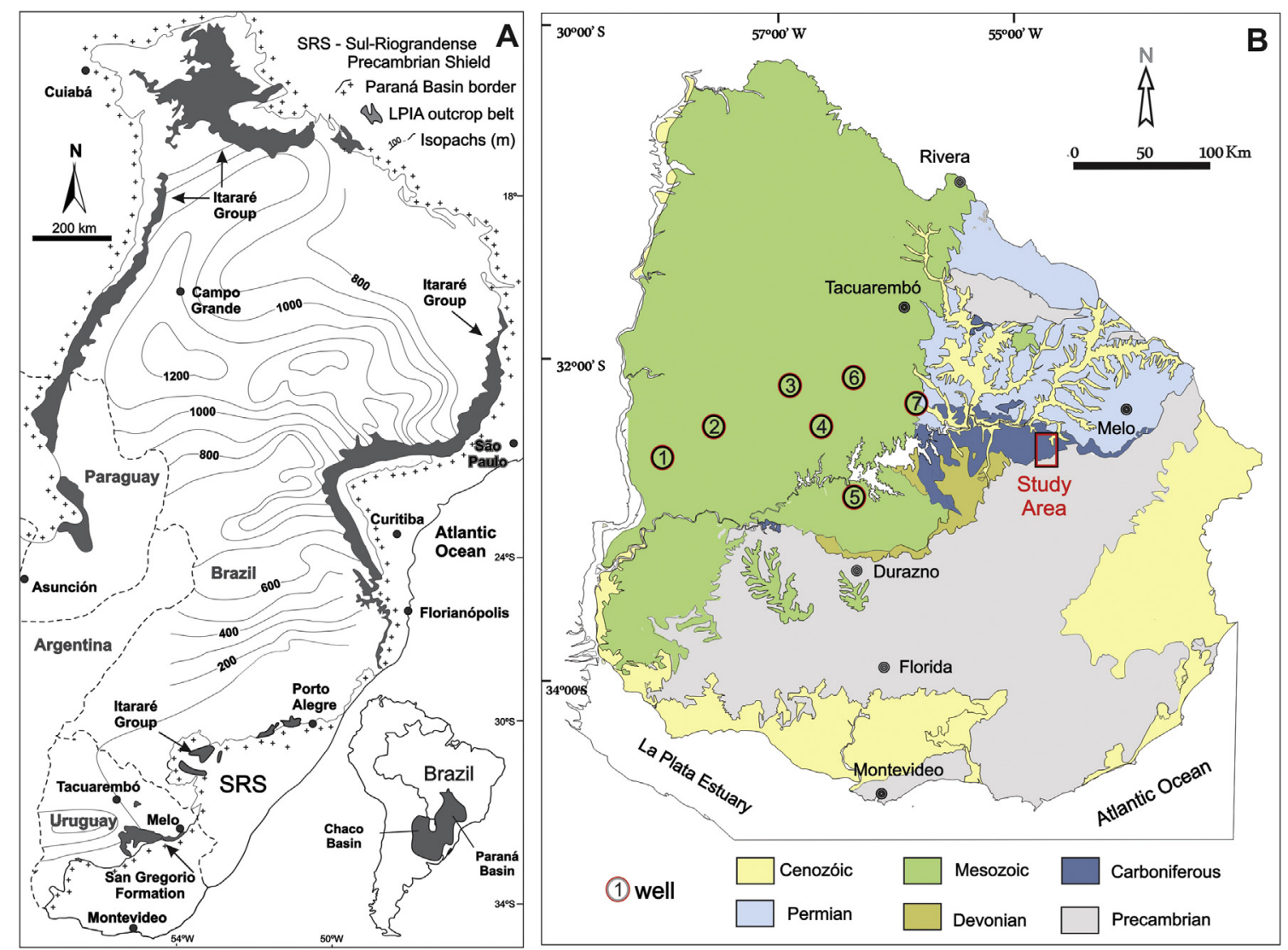

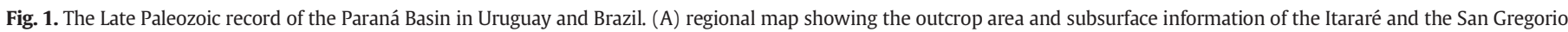

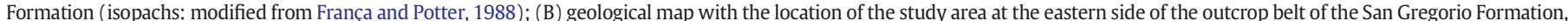
south of the Melo town, Uruguay (wells: $1=$ Ulleste; 2 = Guichón; $3=$ Salsipuedes; $4=$ Cardozo Chico; $5=$ Rincon del Bonete; $6=$ Achar; $7=$ Cuchilla Zamora)

crop out discontinuously along the eastern border of the basin. The glaciogenic succession rests unconformably on pre-Carboniferous basement rocks, and the basal contact is locally marked by uneven erosional surfaces carved by glaciers down into underlying rocks.

In this paper, we report a suite of erosional landforms and associated sedimentary facies belonging to an exhumed and well-exposed late Paleozoic subglacial landscape on Precambrian rocks south of the locality of Cerro de Las Cuentas, Departamento de Cerro Largo, Uruguay (geographical coordinates $32^{\circ} 39^{\prime} 22^{\prime \prime} \mathrm{S}, 54^{\circ} 35^{\prime} 10^{\prime \prime} \mathrm{W}$ ). In Uruguay, the glacial bedrock surface occurs below the glacial succession of the San Gregorio Formation and is composed of well-preserved linear and subparallel erosional landforms. The subglacial landforms were noticed for the first time by Assine et al. (2010), who interpreted them as asymmetric whalebacks.

The erosional landforms and the overlying sedimentary succession provide valuable information on subglacial processes and facies, depositional environments, and the local directions of paleo-ice flow. These data, combined with information from the Itararé Group in southernmost Brazil (e.g., Tomazelli and Soliani, 1982, 1997), offer an excellent opportunity to investigate the dynamics of the Uruguayan ice lobe and its potential extent northward into the Paraná Basin. Moreover, remnants of glacial erosional landforms in Uruguay help to understand the regional paleogeographic scenario of southwestern Gondwana during the LPIA.

\section{The San Gregorio Formation}

The sedimentary records of the LPIA in the Uruguayan Chaco-Parana Basin were formerly recognized by Guillemain (1911) and named the San Gregorio Formation (Bossi, 1966). The unit rests unconformably on Devonian shales and sandstones, or directly on metamorphic and igneous Precambrian crystalline rocks. Exposures can be found at the southeastern border of the basin where the unit is thin and reveals a complex facies association composed of diamictites, mudstones, rhythmites, sandstones, and gravelly sandstones (De Santa Ana, 2004; De Santa Ana et al., 2006a, 2006b). Variable thicknesses for the San Gregorio Formation are recorded across the basin, as revealed by the wells Rincón del Bonete (26 m long), Salsipuedes (253 m long), Guichón NO5 x-1 (290 m long), Paso Ulleste (255 m long), Achar E-1 (155 m long), Cardozo Chico E-1 (254 m long), and Cuchilla Zamora (142 m long) (Fig. 1).

The glacial influence on the San Gregorio Formation is attested by the presence of erosional landforms with polished surfaces and striations. Glaciogenic facies include boulder pavements, tillites, and rhythmites with dropstones (De Santa Ana et al., 2006a). However, most facies are products of mobilization of subglacial sediments downdip by subaqueous gravity-driven mass movements, and turbidity currents that formed thick sandstone packages associated with pebbly sandstones and conglomerates (Goso, 1995).

The stratigraphic record is dominated by glacially-influenced marine sediments as indicated by cephalopods in phosphatic concretions (Closs, 1967a, 1967b, 1969), amphidisc and hemidisc sponges (Kling and Reif, 1969), fish remains (Beltan, 1981), brachiopods (Sprechmann et al., 2001), radiolarians (Braun et al., 2003), acritarchs, algae, and sporomorph assemblages retrieved from outcrops and borehole samples (De Santa Ana et al., 2006a; Beri et al., 2011, 2015). However, the presence of pollen and spores as well as the occurrence of large amounts of plant debris (Soto, 2014) provides evidence for an important terrestrial contribution.

The precise age of the San Gregorio Formation has been a matter of controversy. Studies based on cephalopods/goniatites (Closs, 1967a, 1967b, 1969), radiolarians (Braun et al., 2003), sponges (Kling and 
Reif, 1969), and fishes (Beltan, 1981) assigned a Carboniferous age to the unit, whereas an early Permian age (Asselian and Sakmarian) was ascribed based on continental spores and pollen grains (MarquesToigo, 1970, 1974; De Santa Ana et al., 1993; Beri et al., 2011). According to new palynological zonation (Beri et al., 2015), deposition of the glaciomarine facies would have occurred mainly during the Pennsylvanian, but possibly extended to the early Cisuralian.

The San Gregorio Formation has physical continuity northward with the Itararé Group in the State of Rio Grande do Sul, southern Brazil.
Recent $\mathrm{U}-\mathrm{Pb}$ radiometric dating of zircons of an ash layer in the topmost glacial deposits of the Itararé Group, recovered from a core sample in the Capané paleovalley (Rio Grande do Sul), gave an age of $307.7 \pm 3.1 \mathrm{Ma}$ (Cagliari et al., 2016). New radiometric data of volcanic ash deposits recovered from postglacial coal-bearing in the southern Parana Basin reinforce a Carboniferous age for the glaciation in southwestern Gondwana (Griffis et al., 2017). Based on these radiometric ages and on the fossil content, the studied succession of the San Gregorio Formation is more likely to have been deposited in the late Carboniferous.

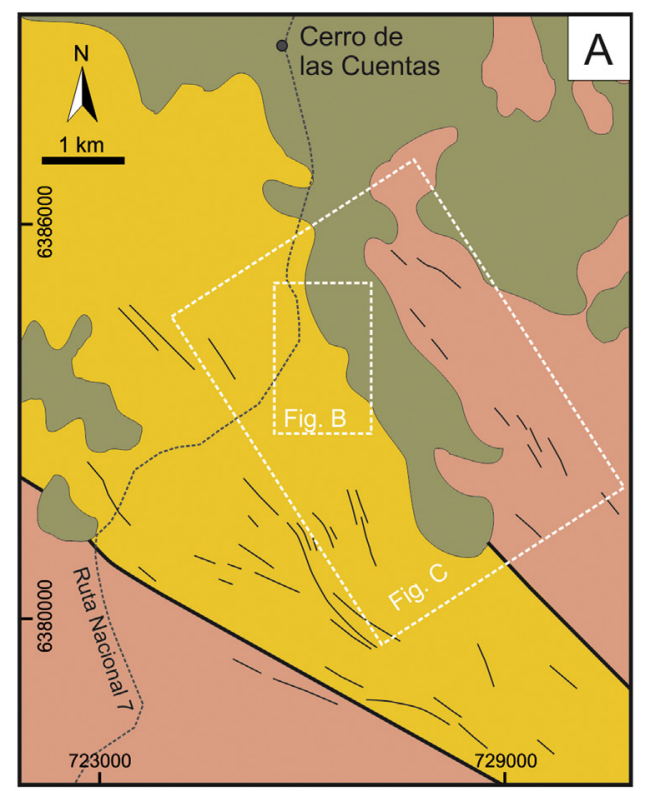

$\square$ Late Paleozoic San Gregorio Fm

$\square$ Ediacaran granitoids

$\square$ Paleoproterozoic crystalline rocks

$\checkmark$ Major Precambrian tectonic boundaries

- Basement structural fabric
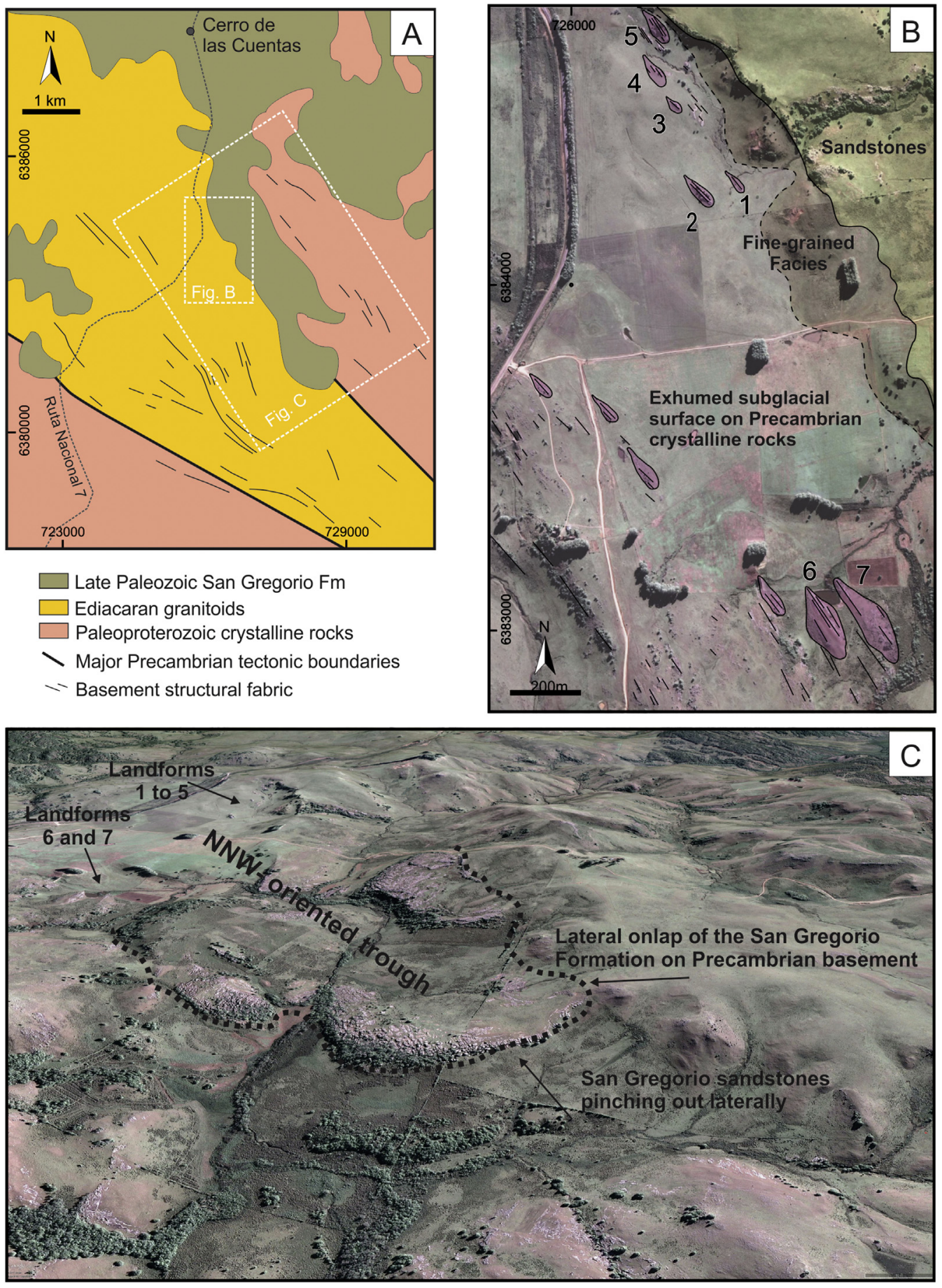

Fig. 2. Geological setting. (A) geologic map (location on Fig. 1B); (B) exhumed subglacial surface with erosional landforms (Google Earth satellite image; numbers 1 to 7 indicate landforms reported in this paper); (C) the glacial facies succession of the San Gregorio Formation occurs in a NNW-oriented trough and onlap laterally Precambrian basement rocks (oblique view of Google Earth 3D satellite image). 


\section{Description of glacial landforms and associated facies}

The study area is located in the E-W-oriented outcrop belt of the San Gregorio Formation (Fig. 1). In this area, the glacigenic deposits are preserved in a NW trough carved on Precambrian rocks. The basement is composed of Paleoproterozoic metamorphic rocks and granitoids of the Nico Perez Terrane as well as Ediacaran granites (e.g., Aubet et al., 2014). These units are bounded by major tectonic lineaments trending SE-NW and present a distinct structural fabric oriented in the same direction (Fig. $2 \mathrm{~A}$ ).

The basal nonconformity is an uneven surface characterized by the presence of a NW-trending trough, up to $40 \mathrm{~m}$ deep and approximately $1.5-\mathrm{km}$-wide, incised roughly parallel to the structure of the basement rocks (Fig. 2B). The sedimentary strata onlap the crystalline basement rocks on the trough margins and pinch out laterally, suggesting that in the studied area, the San Gregorio Formation records the sediment infill of a glacial paleovalley (Fig. 2C).

\subsection{Hard-bed streamlined landforms}

The exhumed glacial paleosurface was sculpted on Precambrian crystalline rocks that immediately underlie the San Gregorio Formation. Elongated, positive features with variable dimensions punctuate the present landscape over up to $2 \mathrm{~km}^{2}$. The landforms are on schists and granites and are glacially smoothed across their entire length and width with no plucked sides. Granite boulders roughly likewise aligned can be present in depressions between positive glacially abraded bedrock landforms, similar to sandy boulder-gravel described in late Pleistocene deposits at Lago Tranquilo in Chilean Patagonia (Glasser and Harrison, 2005).
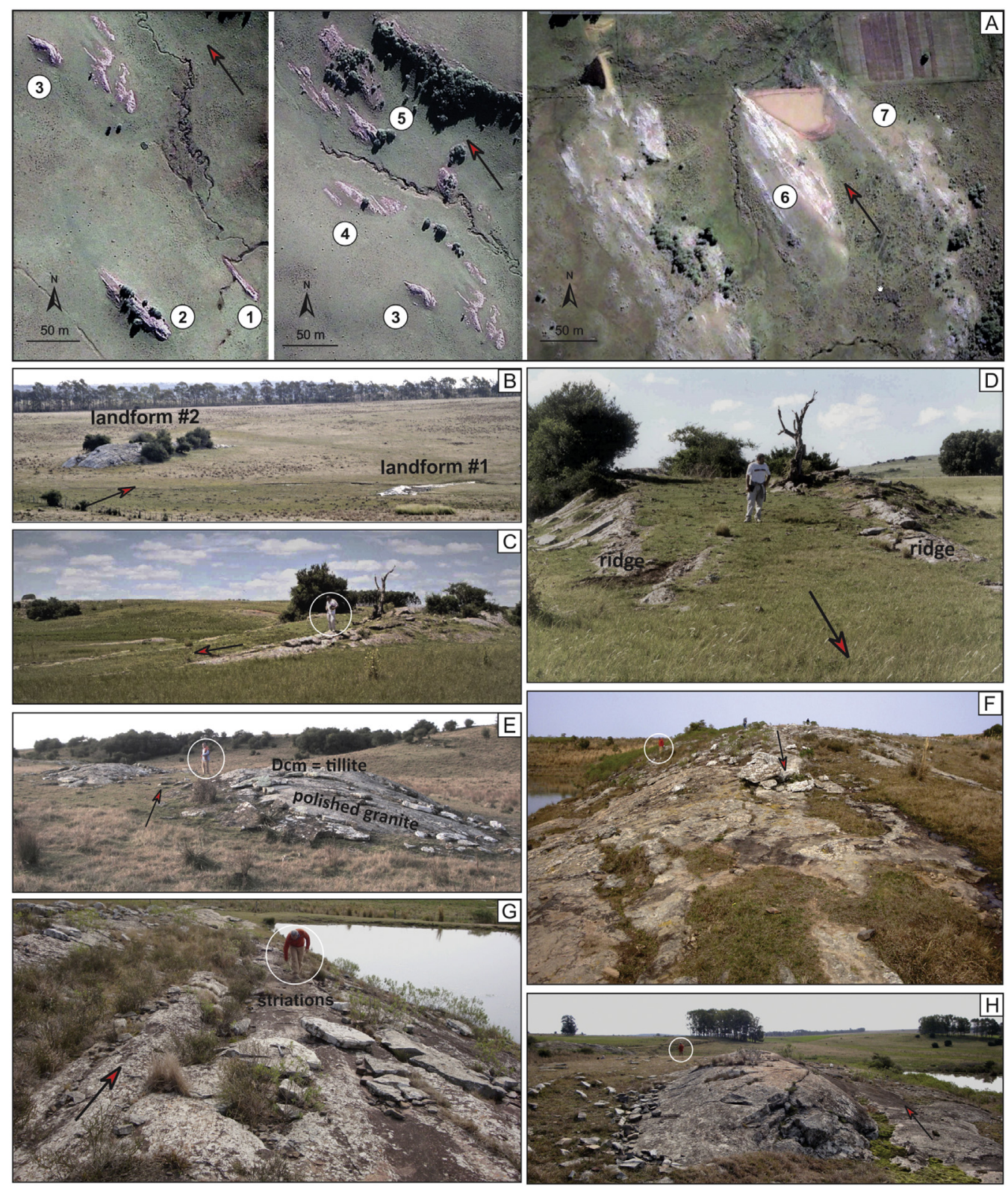

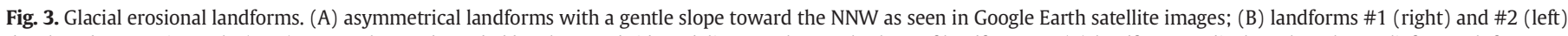

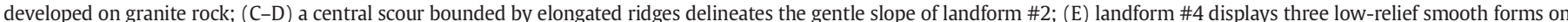

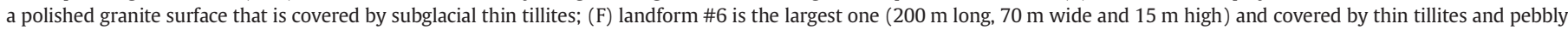

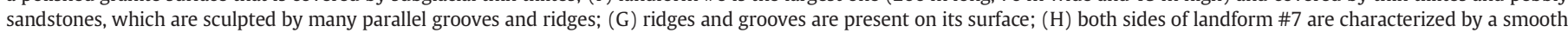
surface upon the underlying rocks. Circled human figure provides scale for field pictures and the arrow indicates the paleo-ice flow. 
When viewed in planform from aerial images, the landforms are drop-shaped, elongated NNW-oriented features (Fig. 2B). They can be described as streamlined erosional landforms (e.g., Krabbendam et al., 2016) of intermediate scale (40-200 m long, 10-60 m wide, and 1-15 $\mathrm{m}$ high). While the size is variable, the geometry is constant since the length is always 4 to 5 times larger than the width. The longitudinal profile exhibits a smooth, convex-up, asymmetric surface characterized by a steeper, SSE dipping slope and a NNW dipping gentler one. The gentler slope is commonly an even surface with abundant parallel NNW-oriented striations and, locally, a highly polished surface on granites (Figs. 3, 4).

Because the slopes are smoothly abraded, lacking the typical glacially plucked (quarried) lee side that characterizes roches moutonnées, these subglacial landforms could be classified as rock drumlins. Contrary to roches moutonnées, rock drumlins exhibit a gentle and smoothed lee slope dipping downflow, commonly described in many glaciated areas (e.g., Dardis et al., 1984; Hanvey, 1987; Ellwanger, 1992; Wysota, 1994; Raukas and Tavast, 1994; Hart, 1995; Evans, 1996; Heroy and Anderson, 2005; Kerr and Eyles, 2007; Spagnolo et al., 2011; Eyles, 2012; Krabbendam et al., 2016). Rock drumlins are commonly assigned to asymmetrical erosional landforms, whereas whalebacks are symmetrical in longitudinal cross-section (Evans, 1996). However, Stokes et al. (2011) proposed the abandonment of the term rock drumlin in favor of the term whaleback, with the addition of the prefix asymmetric for those with clearly asymmetric profiles. This procedure was recommended by Munro-Stasiuk et al. (2013) and we adopted this nomenclature to refer to the several erosional features examined here that collectively form a swarm of asymmetric whalebacks aligned parallel to the regional paleo-ice flow. Late Paleozoic rock drumlins and whalebacks, similar to those of the present study, have been
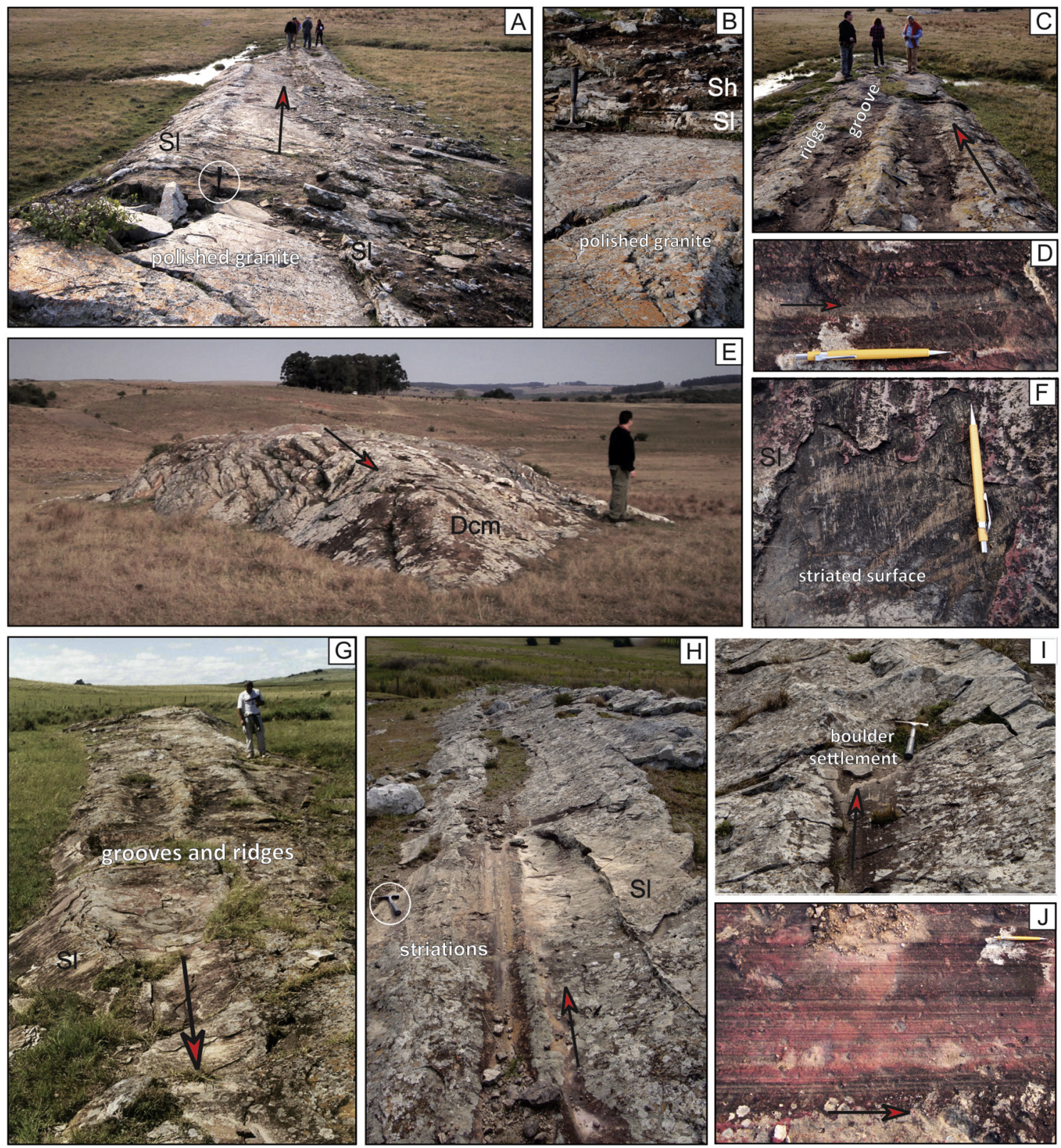

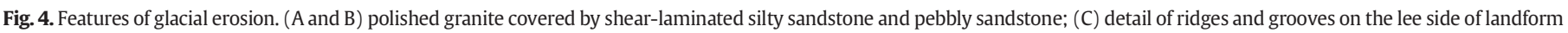

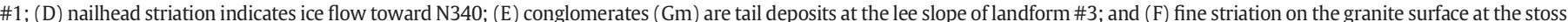

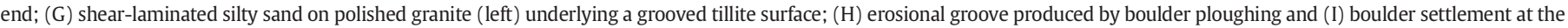

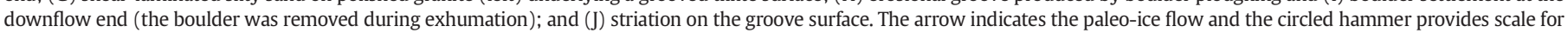
some field pictures. Figures: A-D = landform \#1; E-F = landform \#3; G= landform \#2; H-J = landform \#6. 


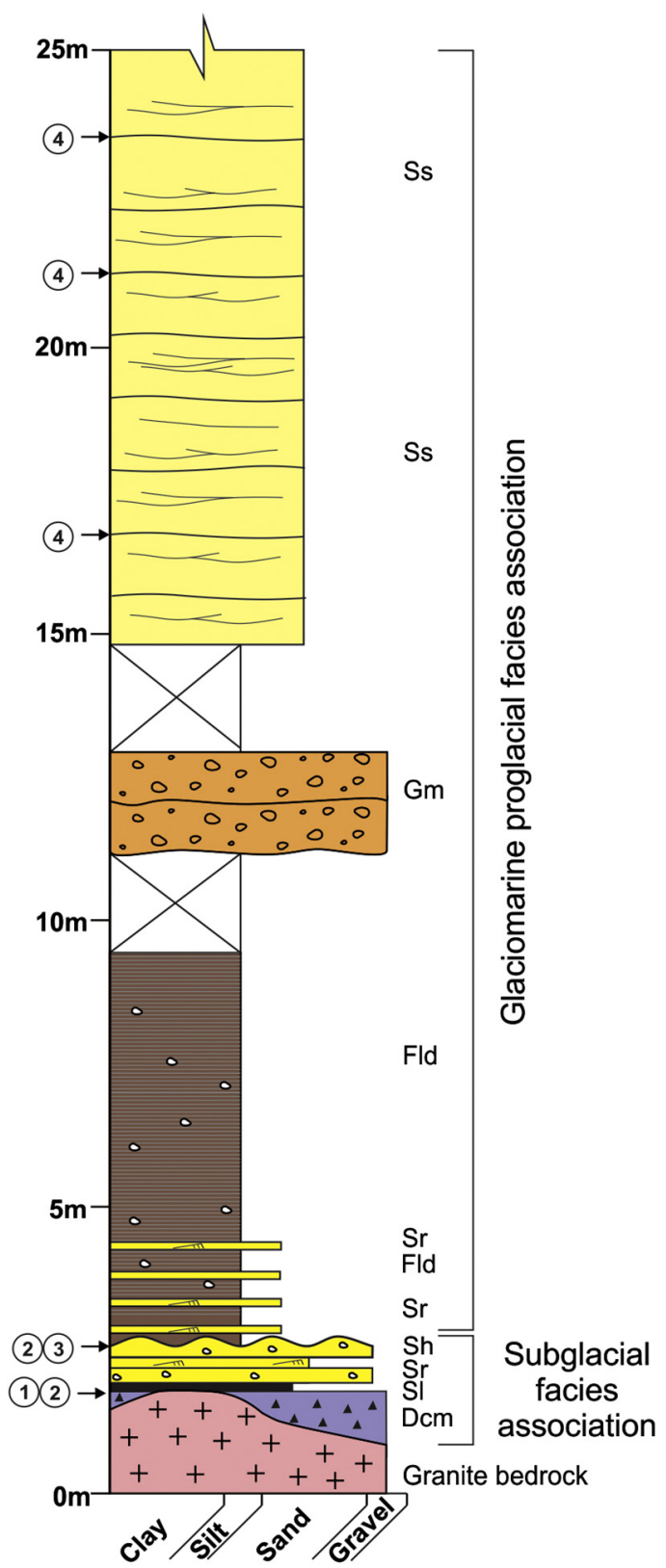

Facies

Swaley cross-stratified sandstone (Ss)

-0 Clast-supported conglomerate $(\mathrm{Gm})$

Laminated mudstones and rhythmites with dropstones (Fld)

$\circ 0$ Horizontally stratified pebbly sandstone (Sh)

$\rightarrow$ Current-rippled sandstone (Sr)

Laminated silty sandstone (SI)

$\triangle$ Clast-rich sandy diamictite (Dcm)

\section{Glacial erosional features}

(4) Soft-sediment striated surface

(3) Ridges and grooves

(2) Parallel striations

(1) Polished surface reported by Bussert (2010) underlying glacial facies of the Edaga Arbi Formation in Northern Ethiopia.

\subsection{Facies succession and soft-sediment striated surfaces}

A well exposed, 30 m-thick facies succession of the San Gregorio Formation overlies the abraded bedrock (Figs. 5, 6). A 10 to $50 \mathrm{~cm}$-thick layer of a highly compacted and massive, clast-rich sandy diamictites (Dcm facies), clast- to matrix-supported, and made up of angular to sub-rounded gravels and boulders of crystalline rocks, drapes the striated/polished surfaces of the whalebacks. These deposits are laterally discontinuous and might form crag-and-tail sediment bodies (e.g., Dionne, 1987) on the lee side of more prominent whalebacks. A cm-scale veneer of homogeneous laminated silty sandstone ( $\mathrm{Sl}$ facies), without oversized clasts, caps the basal clast-rich sandy diamictites and the basement rocks where diamictites are absent.

A $1 \mathrm{~m}$-thick interval of horizontally stratified to massive pebbly sandstones (Sh facies), with intercalated fine-to-medium-grained current-rippled sandstones ( $\mathrm{Sr}$ facies), is present above both the basal clast-rich sandy diamictites and the laminated silty sandstones. The current ripples have foresets dipping to NNW ( $340^{\circ}$ mean azimuth). The top of the pebbly sandstones is molded by ridges and grooves $5-50 \mathrm{~cm}$ deep, a few to hundreds of meters long, and up to $2 \mathrm{~m}$ wide. The grooves are often floored by subparallel striations and some of them have lodged gravels and boulders at their downflow (NW) terminations. Ridges starting in embedded boulders (flutes) were not observed in association with the grooved surface. Linear to curvilinear grooves/striations and ridges are parallel to striations on the basement rocks (azimuth $320^{\circ}$ to $340^{\circ}$ ).

The basal coarse-grained facies are abruptly overlain by an $8 \mathrm{~m}$-thick succession of rhythmites and mudstones, with small sparsely scattered dropstones. The rhythmites are found only in the lower interval and comprise regular, cm-spaced alternations of very fine sand and mud in which sandy layers exhibit locally current ripples.

A sand-prone stratigraphic unit overlies the rhythmite-mudstone unit. The contact is poorly exposed but can be defined as abrupt and erosive because of the presence of a $2 \mathrm{~m}$-thick interval of conglomerates resting directly on the fine-grained facies. The conglomerate beds are dominantly clast supported and massive ( $\mathrm{Gm}$ facies), made up of angular to subrounded metamorphic and granitic pebbles and cobbles, with rare small boulders (up to $45 \mathrm{~cm}$ in size). The grain size varies laterally and vertically within the conglomerate beds, and crudely stratification can be observed locally where the percentage of gravel diminishes, and the conglomerates possess coarse-grained sandstone matrix.

The uppermost sandstone package is approximately $15 \mathrm{~m}$-thick (only the lowermost $10 \mathrm{~m}$ are presented in the vertical log of Fig. 5) and is composed of fine-to-medium-grained amalgamated beds displaying undulated, low-angle swaley cross-stratification (Ss facies), ripples, and rare climbing ripples (facies $\mathrm{Sr}$ ). Intraformational striated surfaces were found on at least four distinct bedding planes within the sandstone package (Fig. 7). The surfaces are flat to slightly undulated and contain straight to curved, parallel striations and elliptical to circular, shallow cavities. Some striated surfaces are laterally discontinuous and bordered by nonstriated berms. They are oriented N20-40E, which is approximately $60^{\circ}$ different from the mean direction of striations and grooves from underlying levels.

\section{Interpretation of landforms, associated facies and stratigraphic succession}

Based on field observations, the San Gregorio Formation in the study area is herein interpreted as a result of glacier advance, occupancy, and

Fig. 5. Vertical stratigraphic profile at Estancia Las Moras (location of the measured section on Fig. 6A). 

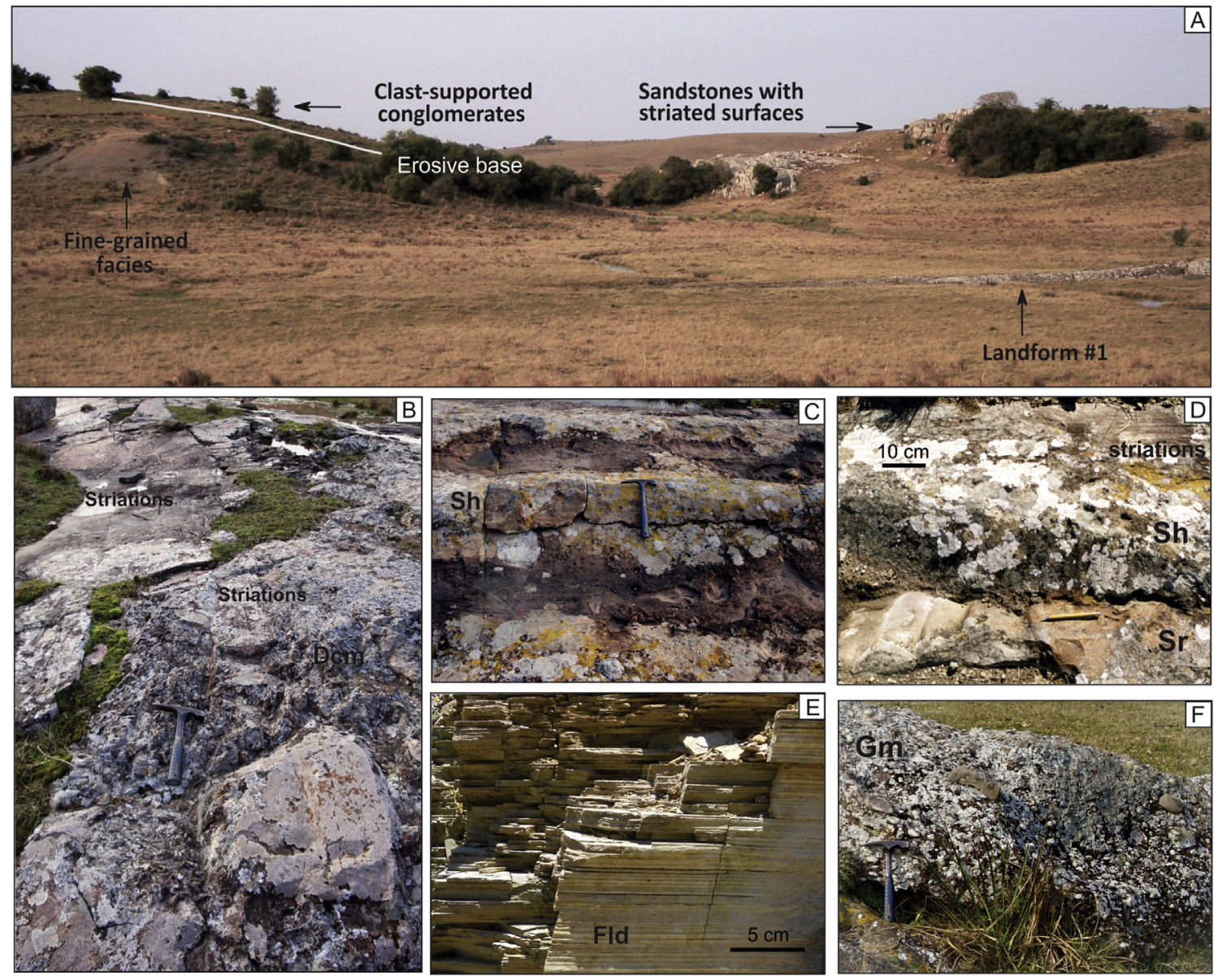

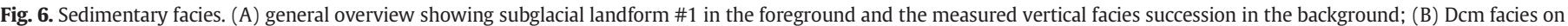

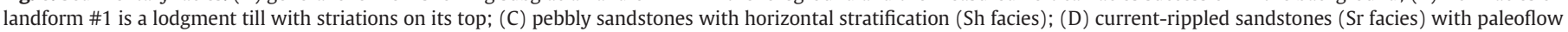

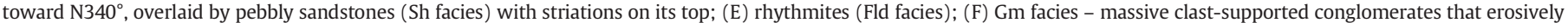
cut fine-grained facies.

subsequent retreat, in which two landforms-facies genetic associations can be recognized: subglacial and proglacial (Fig. 5).

\subsection{Subglacial facies association}

The lowermost facies succession of the San Gregorio Formation encompasses facies closely associated with the hard-bed and the softsediment glacial erosional landforms ( $\mathrm{Dcm}, \mathrm{Sl}, \mathrm{Sr}$, and Sm facies). Several observed features allow us to interpret the streamlined, hard-bed landforms as asymmetrical, subglacial whalebacks, including 1) the presence of smooth, stoss-and-lee profiles with a gentler slope facing downflow (NNW); 2) the superimposition of smaller erosional structures like striations and polished surfaces; 3 ) the presence of scattered granite boulders on the abraded surface; and 4) the existence of overlying compacted, laterally discontinuous, clast-rich sandy diamictites (Dcm facies).

The presence of crag-and-tail structures and lodged boulders at the downflow termination of whalebacks are indicative of subglacial emplacement directly from the debris-rich basal ice (lodgment till), lacking subsequent reworking by water. The lateral discontinuity and the presence of thicker deposits at the lee-sides of asymmetrical whalebacks point to sediment accumulation mainly controlled by substrate irregularities. The thin, laminated silty sandstone (Sl facies) above the basal tillite (Dcm facies) can be interpreted as a product of subglacial deformation and comminution of grains due to shear stress impinged by an advancing glacier onto soft sediments (glaciotectonites). The fine grain size and the absence of oversized clasts suggest sorting by meltwater prior to deformation.

The overlying sandstone interval ( $\mathrm{Sr}$ and $\mathrm{Sh}$ facies) points to meltwater activity because of the better sorting and presence of current-generated structures. The Sh facies was deposited under upper-flow regimes whereas facies Sr record the transition to lowflow conditions. Thus, the alternation of both events suggests fluctuation of the flow regime, probably due to variations in meltwater discharge with time.

The grooves and ridges developed on pebbly sands (Sh facies) consistently trending parallel to the long axis of the whalebacks and were probably formed by plowing, indicating that the ice slid on a soft bed made of subglacially deposited sediment. The lack of flutes, on the other hand, suggests minor participation of sediment accumulation and/or deformation as mechanisms for ridge formation (e.g., Hart and Smith, 1997). The reduced thickness and the fact that grooves and ridges take place over the sandstone facies suggest sand deposition in subglacial cavities formed by the decoupling of the ice from its bed.

The subglacial facies association reported above is consistent with deposition/erosion under wet-based glaciers, where the presence of meltwater favors the glacier to slide on its bed. Increased meltwater discharge during ice-retreat can be evoked to explain the presence of roughly aligned granite boulders, interpreted as ice-marginal deposits and found mainly in the depressions between positive glacially abraded bedrock landforms. 

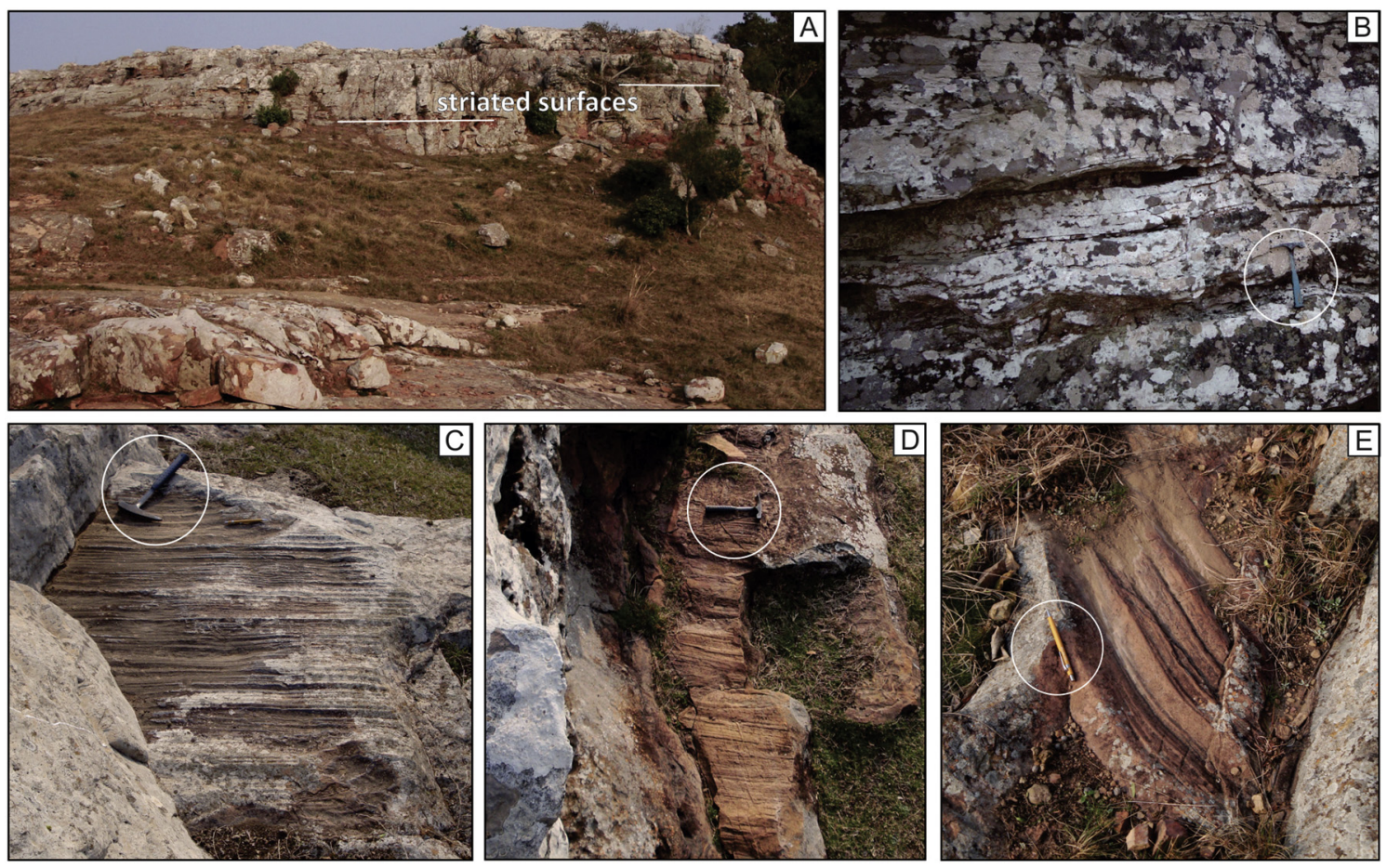

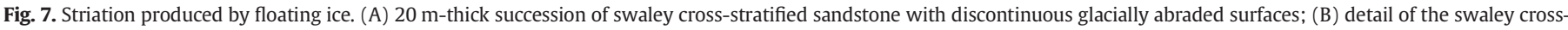
stratified sandstone; (C-D) two levels within the sandstones with soft-sediment striated surfaces; (E) a different level exhibiting curved scours.

\subsection{Glaciomarine proglacial facies association}

This association is the thickest record of the San Gregorio strata exposed in the study area and it is subdivided into a lower mud-rich succession, and an upper sand-rich succession. The lower succession includes mudstones with dropstones that directly overlies the subglacial facies association. These fine-grained facies were studied by Daners and de Santa Ana (2003), who found a palynomorph assemblage mainly composed of continental sporomorphs, with few organic-walled microplankton taxa. These data combined with marine fossils reported in the San Gregorio Formation suggest a low-salinity environment connected with a marine depositional setting.

The presence of rhythmites and mudstone facies with dropstones, and marine fossils in fine-grained facies of the San Gregorio Formation are suggestive of a calving ice margin in contact with a marineinfluenced water body. The retreat of the ice margin promoted marine incursion on the formerly glaciated area, where the presence of dropstones indicates iceberg activity. The abrupt change between subglacial and proglacial facies associations, and the absence of deposits and structures indicative of ice-contact systems, like grounding-line fans and glaciotectonic fold-and-thrust belts (e.g., Van der Wateren, 1994; Isbell, 2010), suggest a rapid glacier retreat from the study area rather than a fluctuating recessional margin.

The upper, coarse-grained succession begins with clast-supported conglomerates ( $\mathrm{Gm}$ facies) that cut erosively the underlying mud-rich facies. We do not observed features that allowed us to interpret these facies as subaerial, missing fluvial facies and bedload-dominated deltaic topsets (e.g., Powell, 1990; Lønne, 1995). Considering the small thickness and the dominantly massive character, we consider that these conglomerate facies are the sedimentary product of rapid deposition from highly concentrated density flows.

The uppermost sandstones were formed in a subaqueous setting as evidenced by the presence of swaley cross-stratification (Ss facies) and symmetrical ripples, which indicate deposition under wave activity. The lack of mudstone interbeds points to an energetic, shallow-water environment, likely the shoreface zone. A subaqueous origin for the sand-rich interval of this association is favored by the presence of discontinuous soft-sediment striated surfaces between sandstone beds. The ice-keel marks indicate that floating icebergs were still present in the depositional setting, suggesting a calving ice-margin in contact with the water body.

The striated surfaces, which are commonly curved, present nonstriated marginal berms, and are oriented in high angles with respect to the regional glacial flow, are very similar to the ice-keel scour marks described in the time-equivalent Itararé Group in the Paraná Basin (Vesely and Assine, 2002, 2014; Vesely et al., 2015) and in other younger deposits elsewhere (e.g., Dionne, 1969; Eyles et al., 2005). These structures are generated by keels of floating ice (icebergs or sea/ lake ice) that plough the sea or lake bottom as the ice moves forced by winds, tides, or currents (Woodworth-Lynas and Dowdeswell, 1994). Ice-keel marks are well reported from Pleistocene to modern environments but their identification in the Paleozoic glacial record is still uncommon compared to other types of ice-related erosional features.

\subsection{Glacial stratigraphy}

The glacially abraded bedrock and the facies stacking composed of subglacial to proglacial deposits can be interpreted in terms of a glacial advance-retreat cycle similar to what have been described from other LPIA successions (e.g., Miller, 1989; França and Potter, 1991; Visser, 1997; Vesely and Assine, 2006; Vesely et al., 2015; Fallgatter and Paim, 2017; Valdez-Buso et al., 2017; Mottin et al., 2018). These deglaciation sequences record complete cycles of glacial advance and retreat either in terrestrial and marine environments and are often almost entirely composed of deposits accumulated during ice-margin retreat or deglaciation (Visser, 1997; Vesely and Assine, 2006).

The $30 \mathrm{~m}$-thick glacigenic sequence described herein has a similar stacking pattern but is thinner than deglaciation sequences recognized, for instance, in the time-equivalent Taciba Formation of the Itararé Group in southern Brazil (Paraná Basin), which can be up to $150 \mathrm{~m}$ thick. The studied succession records only the lower half of typical deglaciation sequences, in which stacking pattern is interpreted to be 
strongly controlled by ice retreat and the depositional products are variable depending on the terrestrial vs. marine setting of the ice margin (e.g., Vesely et al., 2015; Aquino et al., 2016).

The upper half of the deglaciation sequences described from the Itararé Group typically comprises ice-distal, deeper water facies dominated by gravity flows (sandy turbidites and mass-transport deposits), an association not identified in the study area but reported from other outcrop localities in the San Gregorio Formation (e.g., Goso, 1995). It is likely, therefore, that an upper stratigraphic record belonging to the same sequence takes place in the subsurface to the north and is missing in the study area because of post-Paleozoic denudation. Another possible explanation for the reduced thickness is that part of the deglacial stratigraphic record in the study area could have been removed by erosion during the time of the formation of the erosive surface that underlies the upper coarse-grained interval. Considering the rhythmites as offshore facies, it is likely that the sharp-based sandstones were emplaced subaqueously during a subsequent forced regression triggered by baselevel fall (falling-stage systems tract; Plint and Nummedal, 2000). During deglaciation, glacio-isostatic uplifting (rebound) may generate unconformities and cause the accumulation of regressive successions if tectonically-induced sea-level fall and increasing sedimentation rates overcome glacio-eustatic rise (e.g., Boulton, 1990). Similar sedimentary products of glacio-isostatic regressions and associated depositional events have been interpreted from Quaternary (Nutz et al., 2015; Dietrich et al., 2017), late Paleozoic (Mottin et al., 2018) and Ordovician (Le Heron et al., 2006) glacial records.

\section{Paleoglaciologic and paleogeographic implications}

The style of glaciation, paleo ice-flow directions, and the spatial distribution of ice centers are among the major uncertainties concerning the LPIA. Exhumed glacial landscapes and paleo-ice stream pathways provide valuable information on glacial spreading centers and ice sheet dimensions. Recently, an outstanding late Carboniferous exhumed glacial landscape was recognized in Chad using satellite imagery (Le Heron, 2017).

Results of the present study deliver some advances on those issues through the documentation of a well-exposed subglacial paleolandscape and its associated deposits in a relatively poorly studied region of SW Gondwana. The morphology of the pre-Carboniferous substrate in the study area, the types of hard-bed erosional landforms, and the overlying sedimentary facies give clues on the dynamics of the Uruguay Lobe.

The exhumed streamlined landforms take place on the floor of an elongated depression in which at least part of the overlying deposits is confined. The paleorelief of a few tens of meters deep and the width of about $1500 \mathrm{~m}$ are comparable in size to troughs developed beneath fast flowing ice streams (e.g., Evans, 1996; Piasecka et al., 2016) in which streamlined or glacially megalineated hard beds may occur (e.g., Eyles, 2012; Krabbendam et al., 2016). The paleotopography and its streamlined landforms are parallel to the local Precambrian structural fabric, suggesting that weaknesses of the crystalline basement exerted an influence on ice streaming.

Whalebacks have been considered as indicative of high subglacial effective pressures formed under hundreds of meters thick ice (Evans, 1996; Glasser and Bennett, 2004; Bennett and Glasser, 2009). This is because the ice has to be in contact with the whole landform to promote abrasion on all their sides. Under such conditions, cavities at the icebed interface are suppressed, and prevent plucking and the formation of quarried landforms. The examined landforms thus indicate that a significantly thick ice mass advanced on the studied area and sculpted the underlying bedrock. This inference combined with the presence of a shallow trough strongly suggests that the exhumed subglacial landscape was produced by an ice stream associated with an ice sheet instead of a smaller valley-type glacier. The vertical facies sequence of the subglacial association suggests an upward increase in meltwater activity and the presence of cavities. This would indicate a progressively thinner ice cover (e.g., Bennett and Glasser, 2009) that could have been the consequence of climate warming, which culminated in a subsequent deglaciation event.

Subglacial landforms sculpted on bedrock or soft beds are the most reliable indicators of paleo-ice flow direction. The recognition of these structures associated with LPIA deposits in SW Gondwana has resulted in different models depicting the distribution of ice centers (e.g., Frakes and Crowell, 1969, 1970, 1972; Crowell and Frakes, 1972; Martin, 1981; Santos et al., 1996; Isbell et al., 2012; Limarino et al., 2014; Rosa et al., 2016). In the eastern border of the Paraná Basin, numerous occurrences of subglacial landforms on the preglacial substrate or on subglacial diamictite have been documented, constraining paleo-ice flow towards the NW and N (e.g., Bigarella et al., 1967; Rocha-Campos et al., 1988; Trosdtorf et al., 2005; Fallgatter and Paim, 2017). These would indicate an ice-spreading center located to the SE (Windhoek Ice Sheet in Namibia; Visser, 1987) feeding an ice lobe flowing to the NW (Kaokoveld Lobe; Frakes and Crowell, 1970).

In the southeastern area of the Paraná Basin, about $750 \mathrm{~km}$ NE from the study area, the crystalline basement underlying glacial rocks of the Itararé Group contain streamlined landforms draped by thin tillites, which in turn are covered by thick marine mudstones of the Rio do Sul Formation (Rocha-Campos et al., 1988; Rosa et al., 2016). According to Fallgatter and Paim (2017), similar to the present study, the Rio do Sul strata are partially confined in a $30 \mathrm{~m}$ high subglacial topography and all subglacial lineations found in that area are oriented to the NW (azimuth $332^{\circ}$ to $348^{\circ}$ ). Although the aforementioned authors associate this topography with outlet glaciers confined in valleys, an alternative explanation is to consider subglacial troughs below a larger ice sheet. In this hypothesis, the ice-flow directions do not vary spatially and the relief of few tens of meters observed in the studied area contrasts with Quaternary glacial valleys and fjords that typically have depths of several hundreds of meters.

The asymmetrical whalebacks that underlie the San Gregorio Formation in the study area constrain well a paleo-ice flow to the NNW in the Chaco-Parana Basin. Crag-and-tail structures, ridges and grooves, as well as striations preserved on the gentle slopes of whalebacks indicate the same direction of ice movement. This direction of ice movement towards the NNW is corroborated by paleocurrents measured in rippled sandstones produced by subglacial meltwater flows and is similar to that of Cerro de las Cuentas reported by Du Toit (1927).

Subglacial landforms associated with the Itararé Group in the southernmost sector of the Paraná Basin were described on both the northern and southern flanks of the Sul-Riograndense Shield by Tomazelli and Soliani $(1982,1997)$. The landforms are soft-sediment grooved surfaces carved on sandy diamictites a few meters above the preglacial substrate. Reliable kinematic indicators like nailhead furrows and grooves terminating in embedded boulders indicate an average ice flow to the NNW (Tomazelli and Soliani, 1982) coincident with that deduced from the present study. The Itararé facies above the glacial surfaces include mudstones with dropstones and debris-flow diamictites (Tomazelli and Soliani, 1997), indicating a proglacial subaquatic environment similar to that reported for the San Gregorio Formation in the study area.

The NNW paleo-ice flow and the vertical facies succession of the San Gregorio Formation in Estancia Las Moras and of the Itararé Group in Southern Brazil suggest a paleogeographic connection between these two units (Fig. 8). The soft-sediment subglacial landforms of the Itararé Group would indicate a thinner, lobate terminus of ice streams advancing northward. Our results disagree with previous models of ice irradiating from the Rio-Grandense Shield, which is located northward from the study area (e.g., Santos et al., 1996).

A glacial flow to the NNW in this sector of southwest Gondwana concurs with a south-derived Uruguay ice lobe as proposed by Frakes and Crowell (1970). It is also consistent with a glacial source located on Precambrian rocks as envisaged in previous interpretations (França and Potter, 1991; França et al., 1995; De Santa Ana, 2004; Limarino and Spalletti, 2006). The provenance area of the Uruguay Ice Lobe was 


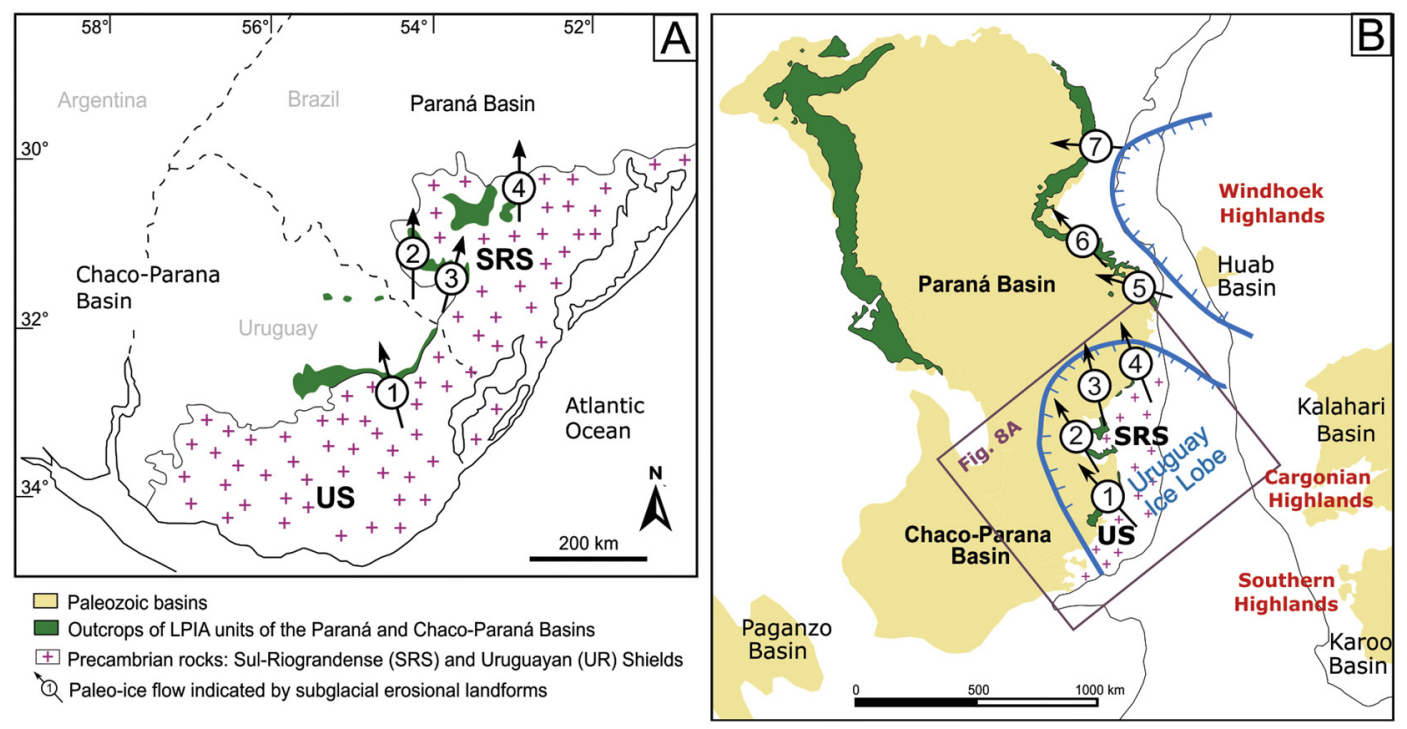

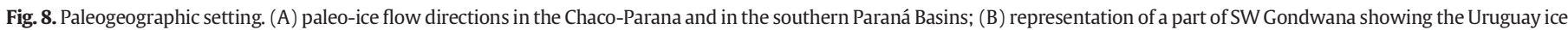

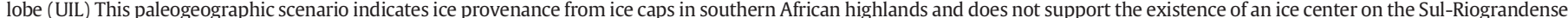

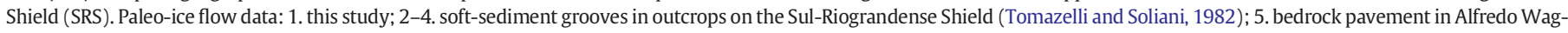
ner (Fallgatter and Paim, 2017); 6. bedrock pavements in Witmarsun, PR (Bigarella et al., 1967); 7. roche moutonnée in Salto, SP (Almeida, 1948).

placed southeast in the highlands of the Uruguayan Shield, and probably far afield in terranes of the present-day southern African territory (e.g., Cargonian and Southern highlands; Visser, 1987). In this scenario, these highlands were the sediment catchment area for the glaciomarine depositional settings in the Chaco-Paraná and Paraná Basins during de late Paleozoic Ice Age.

\section{Conclusions}

The discovery of an exhumed subglacial surface below late Paleozoic deposits of the Chaco-Parana Basin gives the opportunity to explore the ice dynamics, paleoflow directions, and the sedimentary record associated with the Uruguay glacial lobe in the context of the LPIA.

- Erosional landforms exposed in the exhumed surface at Estancia Las Moras encompass numerous asymmetrical streamlined landforms that occupy the floors of a shallow and elongated trough filled with sedimentary facies of the San Gregorio Formation. The structures are interpreted as asymmetrical whalebacks produced by abrasion beneath a several hundred meters thick, and wet-based ice stream flowing to the NNW.

- The overlying facies show a transition from subglacial deposition to proglacial marine sedimentation, recording thinning and rapid disintegration of a tidewater ice margin. Dropstones in fine-grained facies and ice-keel scour marks in between sandstone beds testify the permanence of floating icebergs in the depositional environment during deglaciation.

- Glacial paleoflow inferred herein and that indicated by subglacial landforms in the southern Paraná Basin (Brazil), as well as the similarity between the stratigraphic successions of the San Gregorio Formation and the Taciba Formation of the Itarare Group, suggest the advance of the Uruguay ice lobe for at least $300 \mathrm{~km}$ northward.

- Paleo-ice flows in Uruguay and South Brazil do not support previous models of an ice center irradiating from the Sul-Riograndense Shield, but, rather, indicate that an ice source existed farther southeast during the LPIA, probably in highlands of the present-day southern Africa.

\section{Acknowledgements}

The authors thank the São Paulo Research Foundation (FAPESP grant \# 1998/02183-3) and the National Council for Scientific and
Technological Development (CNPq grant \# 461650/2014-2) for financial support to MLA and FFV. MLA and FFV are research fellows of the CNPq. We are grateful to Neil Glasser for helping in the interpretation of erosional landforms during the first stages of our research, and to Almerio B. França for comments and suggestions that improved the manuscript. Finally, we are very grateful to Jasper Knight, Pierre Dietrich and an anonymous reviewer for careful reading of our manuscript and their many insightful comments.

\section{References}

Almeida, F.F.M., 1948. A "Roche Moutonnée” de Salto, Estado de São Paulo. Boletim Geologia e Metalurgia 5, 112-118.

Aquino, C.D., Valdez-Buso, V., Faccini, U.F., Milana, J.P., Paim, P.S.G., 2016. Facies and depositional architecture according to a jet efflux model of a late Paleozoic tidewater grounding-line system from the Itararé Group (Paraná basin), Southern Brazil. Journal of South American Earth Sciences 67, 180-200.

Assine, M., de Santa Ana, H., Veroslavsky, G., 2010. Subglacial landforms, sedimentary facies and paleo-ice flow in the Permocarboniferous San Gregorio Formation, Chacoparanaense Basin, Uruguay [Abstract]. 18th International Sedimentological Congress, Mendoza, 2010, Abstracts Volume 129.

Aubet, N.R., Pecoits, E., Heaman, L.M., Veroslavsky, G., Gingras, M.K., Konhauser, K.O. 2014. Ediacaran in Uruguay: facts and controversies. Journal of South American Earth Sciences 55, 43-57.

Beltan, L., 1981. Coccocephalichthys tessellatus n. sp. (Pisces, Actinopterygii) from the Upper Carboniferous of Uruguay. 2nd Congresso Latino-Americano de Paleontologia, Porto Alegre, pp. 95-105.

Bennett, M.R., Glasser, N.F., 2009. Glacial Geology - Ice Sheets and Landforms. WileyBlackwell, Chichester (385 pp.).

Beri, Á., Gutiérrez, P., Balarino, L., 2011. Palynostratigraphy of the late Palaeozoic of Uruguay, Paraná Basin. Review of Palaeobotany and Palynology 167, 16-29.

Beri, Á., Gutiérrez, P.R., Balarino, M.L., 2015. The late Paleozoic palynological diversity in southernmost Paraná (Uruguay), Claromecó and Paganzo basins (Argentina), Western Gondwana. Journal of South American Earth Sciences 64 183-189.

Bigarella, J.J., Salamuni, R., Fuck, R.A., 1967. Striated surfaces and related features developed by Gondwana ice sheets (State of Paraná, Brazil). Palaeogeography, Palaeoclimatology, Palaeoecology 3, 265-276.

Bossi, J., 1966. Geología del Uruguay. Colección Ciencias. n² 2. Universidad de la República, Montevideo (419 pp.).

Boulton, G.S., 1990. Sedimentary and sea level changes during glacial cycles and their control on glacimarine facies architecture. In: Dowdeswell, J.A., Scourse, J.D. (Eds.), Glacimarine Environments: processes and sediments. Geological Society Special Publication 53, pp. 15-52.

Braun, A., Sprechmann, P., Gaucher, C., 2003. Stratigraphic age of phosphorite-nodules from the San Gregorio Formation of Uruguay. Neues Jahrbuch für Geologie und Paläontologie Monatshefte 12, 739-748.

Bussert, R., 2010. Exhumed erosional landforms of the Late Palaeozoic glaciation in northern Ethiopia: indicators of ice-flow direction, palaeolandscape and regional ice dynamics. Gondwana Research 18, 356-369. 
Cagliari, J., Philipp, R.P., Buso, V.V., Netto, R.G., Hillebrand, P.K., Cunha Lopes, R., Basei, M.A.S., Faccini, U.F., 2016. Age constraints of the glaciation in the Paraná Basin: evidence from new U-Pb dates. Journal of the Geological Society 173, 871-874

Caputo, M.V., Crowell, J.C., 1985. Migration of glacial centers across Gondwana during Paleozoic Era. Geological Society of America Bulletin 96, 1020-1036.

Closs, D., 1967a. Orthocone cephalopods from the Upper Carboniferous of Argentina and Uruguay. Ameghiniana 5, 123-129.

Closs, D., 1967b. Upper Carboniferous anaptychi from Uruguay. Ameghiniana 5, 145-148.

Closs, D., 1969. Intercalation of goniatites in the Gondwanic glacial beds of Uruguay, Gondwana Stratigraphy. IUGS $1^{\text {st }}$ Gondwana Symposium. UNESCO, Paris, Buenos Aires, pp. 197-212.

Crowell, J.C., Frakes, L.A., 1972. Late Paleozoic Glaciation: part V, Karroo Basin, South Africa. Geological Society of America Bulletin 83, 2887-2919.

Daners, G., de Santa Ana, H., 2003. Primer registro para Uruguay de Deusilites tenuistriatus Gutiérrez, Césari y Archangelsky (Formación San Gregorio, Cuenca Chacoparanense). 12th Simposio Argentino de Paleobotánico y Palinología, Resúmenes 30.

Dardis, G.F., McCabe, A.M., Mitchell, W.I., 1984. Characteristics and origins of lee-side stratification sequences in late Pleistocene drumlins, northern Ireland. Earth Surface Processes and Landforms 9, 409-424.

De Santa Ana, H., 2004. Análise Tectono-Estratigráfica das Seqüências Permotriassica e Jurocretácea da Bacia Chacoparanense Uruguaia ("Cuenca Norte"). (DSc Thesis). Universidade Estadual Paulista (Unesp), Rio Claro. Brasil (274 pp.).

De Santa Ana, H., Beri, A., Coso, C., Daners, G., 1993. Análisis estratigráfico de la Formación San Gregorio (Permico Inferior) en los testigos del Pozo Cerro Largo Sur No 4 (DI. NA MI. GE.), Uruguay. Revista Brasileira de Geociencias 23, 347-351.

De Santa Ana, H., Goso, C., Daners, G., 2006a. Cuenca Norte: estratigrafía del CarboníferoPérmico. In: Veroslavsky, G., Ubilla, M., Martinez, S. (Eds.), Cuencas Sedimentarias de Uruguay: Geología, Paleontología y Recursos Minerales. Facultad de Ciencias, Montevideo, pp. 147-208.

De Santa Ana, H., Veroslavsky, G., Fulfaro, V.J., Rossello, E.A., 2006b. Cuenca Norte: Evolución tectónica y sedimentaria del Carbonífero-Pérmico. In: Veroslavsky, G., Ubilla, M., Martinez S. (Eds.), Cuencas Sedimentarias de Uruguay: Geología, Paleontología y Recursos Minerales. Facultad de Ciencias, Montevideo, pp. 209-256.

Dietrich, P., Ghienne, J.F., Schuster, M., Lajeunesse, P., Nutz, A., Deschamps, R., Roquin, C. Duringer, P., 2017. From outwash to coastal systems in the Portneuf-Forestville deltaic complex (Québec North Shore): anatomy of a forced regressive deglacial sequence. Sedimentology 64, 1044-1078.

Dionne, J.C., 1969. Tidal flat erosion by ice at La Pocatière, St. Lawrence estuary. Journal of Sedimentary Petrology 39, 1174-1181.

Dionne, J.C., 1987. Tadpole rock (rockdrumlin): a glacial streamline moulded form. In Menzies, J., Rose, J. (Eds.), Drumlin Symposium. AA Balkema, Rotterdam, pp. 149-159.

Du Toit, A.L., 1927. A Geological Comparison of South America with South Africa. Carnegie Institution of Washington (Publication 381, 157 pp.).

Ellwanger, D., 1992. Lithology and stratigraphy of some Rhine glacier drumlins (South German Alpine Foreland). Geomorphology 6, 79-88.

Evans, I.S., 1996. Abraded rock landforms (whalebacks) developed under ice streams in mountain areas. Annals of Glaciology 22, 9-16.

Eyles, N., 2012. Rock drumlins and megaflutes of the Niagara Escarpment, Ontario Canada: a hard bed landform assemblage cut by the Saginaw-Huron Ice Stream. Quaternary Science Reviews 55, 34-49.

Eyles, N., Eyles, C.H., Woodworth-Lynas, C., Randall, T.A., 2005. The sedimentary record of drifting ice (early Wisconsin Sunnybrook deposit) in an ancestral ice-dammed Lake Ontario, Canada. Quaternary Research 63, 171-181.

Fallgatter, C., Paim, P.S.G., 2017. On the origin of the Itararé Group basal nonconformity and its implications for the Late Paleozoic glaciation in the Paraná Basin, Brazil. Palaeogeography, Palaeoclimatology, Palaeoecology (in press). https://doi.org/ 10.1016/j.palaeo.2017.02.039.

Frakes, L.A., Crowell, J.C., 1969. Late Paleozoic glaciation: I, South America. Geological Society of America Bulletin 80, 1007-1042.

Frakes, L.A., Crowell, J.C., 1970. Late Paleozoic glaciation: II, Africa exclusive of the Karroo basin. Geological Society of America Bulletin 81, 2261-2286.

Frakes, L.A., Crowell, J.C., 1972. Late Paleozoic glacial geography between the Paraná Basin and the Andean geosyncline. Anais da Academia Brasileira de Ciências 44, 139-145.

França, A.B., Potter, P.E., 1988. Estratigrafia, ambiente deposicional e análise de reservatório do Grupo Itararé (Permocarbonífero), Bacia do Paraná (parte 1). Boletim de Geociências da Petrobrás 2, 147-191.

Franç, A.B., Potter, P.E., 1991. Stratigraphy and reservoir potential of glacial deposits of the Itararé Group (Carboniferous-Permian), Paraná Basin, Brasil. Americam Association of Petroleum Geologists Bulletin 75, 62-85.

França, A.B., Milani, E.J., Schneider, R.L., López Paulsen, O., López Pugliessi, J.M., Suárez, R.S., de Santa Ana, H., Wiens, R., Ferreiro, O., Rossello, E.A., Bianucci, H.A., Flores, F.F.A., Vistalli, M.C., Fernández Seveso, F., Fuenzalida, R.P., Munõz, N., 1995. Phanerozoic correlation in Southern South America. In: Tankard, A., Suarez-Soruco, R, Welsink, H.J. (Eds.), Petroleum Basins of South America. AAPG, Tulsa, pp. 129-161.

Gesicki, A., Riccomini, C., Boggiani, P., 2002. Ice flow direction during Late Paleozoic glaciation in western Paraná Basin, Brazil. Journal of South American Earth Sciences 14 933-939.

Glasser, N.F., Bennett, M.R., 2004. Glacial erosional landforms: origins and significance for palaeoglaciology. Progress in Physical Geography 28, 43-75.

Glasser, N.F., Harrison, S., 2005. Sediment distribution around glacially abraded bedrock landforms (whalebacks) at Lago Tranquilo, Chile. Geografiska Annaler. Series A, Physical Geography 87, 421-430.

Goso, C., 1995. Análise estratigráfica da Formação San Gregorio na borda leste da Bacia Norte Uruguaia. (Master Thesis Thesis). Unesp - Univeridade Estadual Paulista, Rio Claro, Brazil (214 pp.).
Griffis, N., Mundil, R., Montanez, I., Isbell, J., Fedorchuk, N., Vesely, F.F., Iannuzzi, R., Yin, Q.Z., 2017. New stratigraphic framework built on U-Pb single zircon TIMS ages with implications for the timing of the penultimate icehouse (Paraná Basin, Brazil). Geological Society of America Bulletin (in press). https://doi.org/10.1130/B31775.1.

Guillemain, C., 1911. Zur Geologie Uruguays. Zeitschrift der Deutschen Geologischen Gesellschaft 63, 203-220.

Hanvey, P., 1987. Sedimentology of lee-side stratification sequences in late-Pleistocene drumlins, north-west Ireland. In: Menzies, J., Rose, J. (Eds.), Drumlin Symposium. Balkema, Rotterdam, pp. 241-253.

Hart, J.K., 1995. Drumlin formation in southern Anglesey and Arvon, northwest Wales. Journal of Quaternary Science 10, 3-14.

Hart, J.K., Smith, B., 1997. Subglacial deformation associated with fast ice flow, from the Columbia Glacier, Alaska. Sedimentary Geology 111, 177-197.

Heroy, D.C., Anderson, J.B., 2005. Ice-sheet extent of the Antarctic Peninsula region during the Last Glacial Maximum (LGM)-insights from glacial geomorphology. Geological Society of America Bulletin 117, 1497-1512.

Isbell, J.L., 2010. Environmental and paleogeographic implications of glaciotectonic deformation of glaciomarine deposits within Permian strata of the Metschel Tillite, southern Victoria Land, Antarctica. In: Isbell, J.L., López-Gamundí, O.R., Buatois, L.A. (Eds.), Late Paleozoic Glacial Events and Postglacial Transgression in Gondwana. Geological Society of America Special Paper 468, pp. 81-100.

Isbell, J.L., Henry, L.C., Gulbranson, E.L., Limarino, C.O., Fraiser, M.L., Koch, Z.J., Ciccioli, P.L., Dineen, A.A., 2012. Glacial paradoxes during the late Paleozoic ice age: evaluating the equilibrium line altitude as a control on glaciation. Gondwana Research 22, 1-19.

Kerr, M., Eyles, N., 2007. Origin of drumlins on the floor of Lake Ontario and in upper New York State. Sedimentary Geology 192, 7-20.

Kling, S.A., Reif, W.E., 1969. The Paleozoic history of amphidisc and hemidisc sponges; new evidence from the Carboniferous of Uruguay. Journal of Paleontology 43, $1429-1434$

Krabbendam, M., Eyles, N., Putkinen, N., Bradwell, T., Arbelaez-Moreno, L., 2016. Streamlined hard beds formed by palaeo-ice streams: a review. Sedimentary Geology 338, 24-50.

Le Heron, D.P., 2017. An exhumed Paleozoic glacial landscape in Chad. Geology 46, 91-94.

Le Heron, D.P., Craig, J., Sutcliffe, O.E., Whittington, R., 2006. Late Ordovician glaciogenic reservoir heterogeneity: an example from the Murzuq Basin, Libya. Marine and Petroleum Geology 23, 655-677.

Limarino, C.O., Spalletti, L.A., 2006. Paleogeography of the upper Paleozoic basins of southern South America: an overview. Journal of South American Earth Sciences 22, 134-155.

Limarino, C.O., Césari, S.N., Spalletti, L.A., Taboada, A.C., Isbell, J.L., Geuna, S., Gulbranson, E.L., 2014. A paleoclimatic review of southern South America during the late Paleozoic: a record from icehouse to extreme greenhouse conditions. Gondwana Research $25,1396-1421$

Lønne, I., 1995. Sedimentary facies and depositional architecture of ice-contact glaciomarine systems. Sedimentary Geology 98, 13-43.

López-Gamundí, O.R., Buatois, L.A., 2010. Introduction: Late Paleozoic glacial events and postglacial transoressions in Gondwana. In: López Gamundi, O.R. Buatois, LA. (Eds.), Late Paleozoic Glacial Events and Postglacial Transgressions in Gondwana. Geological Society of America Special Paper 468, pp. v-viii.

Marques-Toigo, M., 1970. Anabaculites nov, gen., a new miospore genus from San Gregorio Formation of Uruguay. Ameghiniana 7, 79-82.

Marques-Toigo, M., 1974. Some new species of spores and pollens of Lower Permian age from the San Gregorio Formation in Uruguay. Anais Academia Brasileira de Ciências 46, 601-616.

Martin, H., 1981. The late Palaeozoic Dwyka Group of the south Kalahari Basin in Namibia and Botswana and the subglacial valleys of the Kaokoveld in Namibia. In: Hambrey, M.J., Harland, W.B. (Eds.), Earth's Pre-Pleistocene Glacial Record. Cambridge University Press, Cambridge, pp. 61-66.

Miller, J.M.G., 1989. Glacial advance and retreat sequences in a Permo-Carboniferous section, central Transantarctic Mountains. Sedimentology 36, 419-430.

Mottin, T.E., Vesely, F.F., Rodrigues, M.C.N.L., Kipper, F., Souza, P.A., 2018. The paths and timing of late Paleozoic ice revisited: new stratigraphic and paleo-ice flow interpretations from a glacial succession in the upper Itararé Group (Paraná Basin, Brazil). Palaeogeography, Palaeoclimatology, Palaeoecology 490, 488-504.

Munro-Stasiuk, M., Heyman, J., Harbor, J., 2013. Erosional Features. In: Shroder, J.F. (Ed.), Treatise on Geomorphology - Vol 8 - Glacial and Periglacial Geomorphology. Academic Press, San Diego, pp. 83-99.

Nutz, A., Ghienne, J.F., Schuster, M., Dietrich, P., Roquin, C., Hay, M.B., Bouchette, F. Cousineau, P.A., 2015. Forced regressive deposits of a deglaciation sequence: example from the Late Quaternary succession in the Lake Saint-Jean basin (Québec, Canada). Sedimentology 62, 1573-1610.

Piasecka, E.D., Winsborrow, M.C., Andreassen, K., Stokes, C.R., 2016. Reconstructing the retreat dynamics of the Bjørnøyrenna Ice Stream based on new 3D seismic data from the central Barents Sea. Quaternary Science Reviews 151, 212-227.

Plint, A.G., Nummedal, D., 2000. The falling stage systems tract: recognition and importance in sequence stratigraphic analysis. In: Hunt, D., Gawthorpe, R.L. (Eds.), Sedimentary Response to Forced Regression. Geological Society of London, Special Publication 172, pp. 1-17.

Powell, R.D., 1990. Glacimarine processes at grounding-line fans and their growth to icecontact deltas. In: Dowdeswell, J.A., Scourse, J.D. (Eds.), Glacimarine Environments: Processes and Sediments. Geological Society of London, Special Publication 53, pp. 53-73.

Powell, C.M., Li, Z.X., 1994. Reconstruction of the Panthalassan margin of Gondwanaland. In: Veevers, J.J., Powell, C.M. (Eds.), Permian-Triassic Pangean Basins and Foldbelts along the Panthalassan Margin of Gondwanaland. vol. 184, pp. 5-9 Geological Society of America Memoir. 
Raukas, A., Tavast, E., 1994. Drumlin location as a response to bedrock topography on the southeastern slope of the Fennoscandian Shield. Sedimentary Geology 91, 373-382.

Rocha-Campos, A.C., Machado, L.C.R., Santos, P.R., Canuto, J.R., Castro, J.C., 1988. Pavimento estriado da glaciação Neo-Paleozóica em Alfredo Wagner, SC, Brasil. Boletim IGUSP (Série Científica) 19 pp. 39-46.

Rosa, E.L.M., Vesely, F.F., França, A.B., 2016. A review on late Paleozoic ice-related erosional landforms in the Paraná Basin: origin and paleogeographical implications. Brazilian Journal of Geology 46, 147-166.

Santos, P.R., Rocha-Campos, A.C., Canuto, J.R., 1996. Patterns of Late Palaeozoic deglaciation in the Paraná Basin, Brazil. Palaeogeography, Palaeoclimatology, Palaeoecology $125,165-184$.

Soto, M., 2014. Geología, geofísica y geoquímica de la región de Pepe Núñez, Cuenca Norte (Uruguay). (Master Thesis). Universidad de la República, Montevideo (249 pp.).

Spagnolo, M., Clark, C.D., Hughes, A.L.C., Dunlop, P., 2011. The topography of drumlins; assessing their long profile shape. Earth Surface Processes and Landforms 36, 790-804.

Sprechmann, P., Da Silva, J., Gaucher, C., Montaña, J., Herrera, Z., 2001. Nuevos hallazgos fósiles en concreciones de la Formación San Gregorio del Uruguay e implicancias paleoecológicas y paleoclimáticas. $2^{\text {nd }}$ Simposio Argentino del Paleozoico Superior (Resúmenes 28).

Stokes, C.R., Spagnolo, M., Clark, C.D., 2011. The composition and internal structure of drumlins: complexity, commonality, and implications for a unifying theory of their formation. Earth-Science Reviews 107, 398-422.

Tomazelli, L.J., Soliani, E., 1982. Evidências de atividade glacial no Paleozóico Superior do Rio Grande do Sul, Brasil. $32^{\circ}$ Congresso Brasileiro de Geologia. Sociedade Brasileira de Geologia, Salvador, pp. 1378-1391.

Tomazelli, L.J., Soliani, E., 1997. Sedimentary facies and depositional environments related to Gondwana glaciation in Batovi and Suspiro regions, Rio Grande Do Sul, Brazil. Journal of South American Earth Sciences 10, 295-303.

Trosdtorf Jr., I., Assine, M.L., Vesely, F.F., Rocha-Campos, A.C., Dos Santos, P.R., Tomio, A., 2005. Glacially striated, soft sediment surfaces on late Paleozoic tillite at São Luiz do Purunã, PR. Anais da Academia Brasileira de Ciências 77, 367-378.

Valdez-Buso, V., Aquino, C.D., Paim, P.S.G., Souza, P.A., Mori, A.L., Fallgatter, C., Milana, J.P., Kneller, B., 2017. Late Paleozoic glacial cycles and subcycles in western Gondwana: correlation of surface and subsurface data of the Paraná Basin, Brazil. Palaeogeography, Palaeoclimatology, Palaeoecology in press. https://doi.org/10.1016/j.palaeo.2017.09.004.

Van der Wateren, F.M., 1994. Proglacial subaquatic outwash fan and delta sediments in push moraines - indicators of subglacial meltwater activity. Sedimentary Geology 91, 145-172.

Vesely, F.F., Assine, M.L., 2002. Superfícies estriadas em arenitos do Grupo Itararé produzidas por gelo flutuante, sudeste do Estado do Paraná. Revista Brasileira de Geociencias 32, 587-594.

Vesely, F.F., Assine, M.L., 2006. Deglaciation sequences in the Permo-Carboniferous Itararé Group, Paraná Basin, southern Brazil. Journal of South American Earth Sciences 22 156-168.

Vesely, F.F., Assine, M.L., 2014. Ice-keel scour marks in the geological record: evidence from carboniferous soft-sediment striated surfaces in the Paraná Basin, southern Brazil. Journal of Sedimentary Research 84, 26-39.

Vesely, F.F. Trzaskos, B. Kipper, F. Assine, M.L, Souza, P.A, 2015. Sedimentary record of a fluctuating ice margin from the Pennsylvanian of western Gondwana: Paraná Basin, southern Brazil. Sedimentary Geology 326, 45-63.

Visser, J., 1987. The palaeogeography of part of southwestern Gondwana during the Permo-Carboniferous glaciation. Palaeogeography, Palaeoclimatology, Palaeoecology 61, 205-219.

Visser, J.N.J., 1997. Deglaciation sequences in the Permo-carboniferous Karoo and Kalahari basins of southern Africa: a tool in the analysis of cyclic glaciomarine basin fills. Sedimentology 44, 507-522.

Woodworth-Lynas, C.M.T., Dowdeswell, J.D., 1994. Soft-sediment striated surfaces and massive diamiction facies produced by floating ice. In: Deynoux, M., Miller, J.M.J., Domack, E.W., Eyles, N., Fairchild, I.J., Young, G.M. (Eds.), Earth's Glacial Record. Cambridge University Press, Cambridge, pp. 241-259.

Wysota, W., 1994. Morphology, internal composition and origin of drumlins in the southeastern part of the Chelmno-Dobrzyń Lakeland, North Poland. Sedimentary Geology $91,345-364$. 